\title{
Channel catfish reovirus (CRV) inhibits replication of channel catfish herpesvirus (CCV) by two distinct mechanisms: viral interference and induction of an anti-viral factor
}

\author{
V. G. Chinchar ${ }^{1, *}$, O. Logue $^{1}$, A. Antao ${ }^{1}$, G. D. Chinchar ${ }^{2}$ \\ ${ }^{1}$ Department of Microbiology, University of Mississippi Medical Center, Jackson, Mississippi 39216, USA \\ ${ }^{2}$ Department of Natural Sciences, Tougaloo College, Tougaloo, Mississippi 39174, USA
}

\begin{abstract}
Catfish reovirus (CRV), a double-stranded RNA virus, inhibited channel catfish herpesvirus (CCV) replication by 2 different mechanisms: (1) directly as a consequence of its own replication, and (2) indirectly due to the induction of an anti-viral factor. In the former, prior infection with CRV significantly reduced subsequent $\mathrm{CCV}$ protein synthesis and virus yield. CRV-mediated interference was greatest when CRV infection preceded CCV infection by $16 \mathrm{~h}$, and was least when cell cultures were simultaneoulsy infected with both viruses. In the latter case, infection of channel catfish ovary (CCO) cultures with UV-inactivated CRV resulted in the synthesis (or release) of an anti-viral factor. Cells producing the factor were protected from CCV infection, as were cells which had been treated with spent culture medium containing anti-viral activity. Interestingly an anti-viral activity was constitutively present in long-term cultures of catfish $\mathrm{T}$ cells and macrophages. Whether this factor and the one induced by UV-inactivated CRV are identical is not known, but analogy to mammalian systems suggests that the former may be similar to type II interferon, whereas the latter may be the piscine equivalent of type I interferon. These results suggest that UV-inactivated CRV may prove useful in the induction and characterization of interferon-like anti-viral proteins in the channel catfish and that long-term cultures of catfish $\mathrm{T}$ cells and monocytes may serve as a ready source of additional anti-viral factors.
\end{abstract}

KEY WORDS: Viral interference · Anti-viral factor - Interferon · Catfish reovirus - Channel catfish herpesvirus · Catfish lymphoid cell lines

\section{INTRODUCTION}

Viruses are capable of inhibiting not only cellular macromolecular synthesis, but also the replication of co-infecting heterologous or homologous viruses. The ability of one virus to interfere with the replication of another virus is termed viral interference and is due to one of several mechanisms (Younger \& WhitakerDowling 1994). (1) Infection with one virus may inhibit replication of a second virus by blocking virus entry due to down-regulation of viral receptors or to competition between viruses for a common receptor (Steck \& Rubin 1966). (2) Alternatively, replication by the initially infecting virus may inhibit host cell functions that

•E-mail:vgregc@fiona.umsmed.edu are required by the super-infecting virus or the first virus may block heterologous virus replication directly. For example, poliovirus blocks replication of superinfecting vesicular stomatitis virus (VSV) by inhibiting VSV translation, whereas VSV inhibits replication of super-infecting influenza A virus by blocking influenza virus transcription (Younger \& WhitakerDowling 1994). Likewise DNA viruses also block replication of super-infecting viruses. The iridovirus frog virus 3 (FV3) inhibits replication of vaccinia virus, VSV, and equine herpesvirus type 1 (Aubertin et al. 1970, Tannenbaum et al. 1979, Chinchar \& Caughman 1986). (3) Finally, interference may also be mediated by defective interfering particles or temperature sensitive ( $t s)$ mutants that inhibit the replication of wild type virus (Ramig 1990). 
In addition to the above mechanisms, viruses also block replication of a second virus by induction of interferon or other anti-viral factors. Although interferon-mediated anti-viral effects are well characterized in mammals (Weissman \& Weber 1986, Marcus 1994, Vilcek \& Sen 1996), much less is known about the role they play in lower vertebrates (Yano 1996). Interferon-like activities have been identified in a variety of fish species, but definitive identification based on physiochemical and genetic properties is lacking (Beasley et al. 1966, Oie \& Loh 1971, De Sena \& Rio 1975, Eaton 1990, Graham \& Secombes 1990, RogelGaillard et al. 1993, Snegaroff 1993, Yano 1996). Furthermore, despite considerable effort, interferon genes from lower vertebrates (i.e. fish, amphibians, and reptiles) have not yet been cloned and sequenced.

Because reoviruses are good inducers of interferon (Oie \& Loh 1971, Sekellick et al. 1994, Nibert et al. 1996), we examined the ability of channel catfish reovirus (CRV; Family reoviridae; genus aquareovirus) to block replication of channel catfish herpesvirus (CCV) following either productive infection or exposure to UV-inactivated CRV (UV-CRV). We observed that productive infection with CRV blocked subsequent replication of CCV and that exposure to UV-CRV induced the synthesis (or release) of an anti-viral factor that inhibited CCV replication. Moreover, several long-term catfish lymphoid cell lines constitutively synthesized a functionally similar anti-viral factor. These results extend the phenomenon of viral interference to viruses infecting catfish. Furthermore, they suggest that UVCRV may be an excellent inducer of anti-viral proteins in teleosts and that catfish $\mathrm{T}$ cell and macrophage lines may be a good source of anti-viral cytokines.

\section{METHODS}

Cells and viruses. Channel catfish ovary ( $\mathrm{CCO}$ ) and brown bullhead (BB) cells were obtained from L. Hanson (College of Veterinary Medicine, Mississippi State University, USA) and the American Type Culture Collection (CCL 59), respectively. Both cell lines were maintained in Dulbecco's modified Eagle's medium (DMEM) containing 5\% fetal calf serum (FCS). Catfish long-term lymphoid cell lines 42TA, CF-59, and 1G8 were established and maintained in AL medium supplemented with 5\% catfish serum (AL5) as described by Miller et al. (1994a). 42TA is a macrophage cell line (Clem et al. 1996), 1 G8 is a clonal B cell line (Miller et al. 1994b, Wilson et al. 1997), and CF-59 is a putative T cell line that arose after stimulation with phorbol 12 myristate-13-acetate/calcium ionophore. Cell lines were cultured at $27^{\circ} \mathrm{C}$ in a humidified incubator in the presence of $5 \% \mathrm{CO}_{2}$.
$\mathrm{CCV}$ was obtained from the American Type Culture Collection (Auburn 1, clone A strain, VR-665) and propagated in $\mathrm{CCO}$ cells at $28^{\circ} \mathrm{C}$ (Bowser \& Plumb $1980 \mathrm{a}, \mathrm{b})$. Viral titers were determined by plaque assay on CCO cells. CRV (Amend et al. 1984), obtained from R. Hedrick (University of California, Davis, USA), was grown either in $\mathrm{BB}$ or $\mathrm{CCO}$ cells and the virus titer, i.e. the $\log _{10} 50 \%$ tissue culture infectious dose (TCID ${ }_{50}$ ), calculated by the method of Reed \& Muench (1938). Because in our hands CRV does not plaque on CCO cells, the $\mathrm{CCV}$ titer in mixed infections of $\mathrm{CCV}$ and CRV was determined by plaque assay on CCO cells.

Viral interference assays. CCO cells were infected with CRV or UV-CRV at a nominal multiplicity of infection (MOI) of 0.1 and 1.0 TCID $_{50}$ cell $^{-1}$ either $16 \mathrm{~h}$ before or at the same time as infection with CCV. Virus was allowed to adsorb for $1 \mathrm{~h}$, after which time the inoculum was removed and the cultures re-fed with growth medium. For radiolabeling viral proteins, growth medium lacking unlabeled methionine but containing $\left[{ }^{35} \mathrm{~S}\right]$ methionine $\left(\sim 25 \mathrm{Ci} \mathrm{ml}^{-1}\right)$ was added $4 \mathrm{~h}$ after $\mathrm{CCV}$ infection (i.e. $20 \mathrm{~h}$ after CRV infection). After $2 \mathrm{~h}$ the labeling medium was removed, and the cells solubilized in buffer containing sodium dodecyl sulphate (SDS) and 2-mercaptoethanol (Laemmli 1970). Radiolabeled proteins were separated by SDS-polyacrylamide gel electrophoresis (SDS-PAGE) and visualized by autoradiography (Laemmli 1970). The development of cytopathic effects (CPE) was monitored in single and mixed infections by microscropy, and CCV replication was quantitated by plaque assay on $\mathrm{CCO}$ cells.

Induction of an anti-viral factor by UV-CRV. CRV ( $3 \mathrm{ml}$ per $100 \mathrm{~mm}$ tissue culture dish) was inactivated by UV irradiation (150 mJ) using a Bio-Rad GS GeneLinker. Eight day old CCO cultures were infected with UV-CRV at a nominal MOI of 0.1 and $1.0 \mathrm{TCID}_{50} \mathrm{cell}^{-1}$. Virus was allowed to attach for $1 \mathrm{~h}$, after which the inoculum was removed and the cultures incubated at $27^{\circ} \mathrm{C}$ in DMEM containing 2 to $5 \% \mathrm{FCS}$. At the indicated times post infection, the culture medium was harvested and assayed for anti-viral activity in a challenge assay (see below). Where noted, mock- and UV-CRV-treated CCO cultures were infected with $\mathrm{CCV}$ and monitored for $\mathrm{CCV}$-induced $\mathrm{CPE}$ and virion production $48 \mathrm{~h}$ later.

Challenge assays. A challenge assay, similar to that described by Renault et al. (1991), was used to determine whether anti-viral activity was present in spent culture medium (SCM) harvested from UV-CRVinfected $\mathrm{CCO}$ cells or catfish lymphoid cell lines. Approximately $10^{5} \mathrm{CCO}$ cells in $100 \mu \mathrm{l}$ of growth medium were seeded into 96 -well plates containing an equal volume of increasing 2 -fold dilutions of SCM. After overnight incubation, the cultures were challenged by 
addition of $50 \mu \mathrm{l}$ of medium containing $~ 1800$ plaqueforming units (PFU) CCV to each well and incubated at $28^{\circ} \mathrm{C}$ for an additional $48 \mathrm{~h}$. At that time the medium was removed and the cultures stained with $1 \%$ crystal violet in $70 \%$ ethanol. After $5 \mathrm{~min}$, the dye was removed and the plates washed with water until no residual dye remained. Anti-viral titers were calculated by multiplying the last dilution that showed $>50 \%$ protection of the monolayer by 2 (to reflect the addition of an equal volume of cell suspension) and expressed as inhibitory units (IU) per milliliter. simultaneous CRV and CCV infections were performed. To determine the impact of CRV infection on subsequent CCV replication, 3 assays were employed: (1) viral protein synthesis was monitored from 4 to $6 \mathrm{~h}$ post CCV infection (i.e. 20 to $22 \mathrm{~h}$ post CRV infection) by radiolabeling infected cultures with $\left[{ }^{35} \mathrm{~S}\right]$ methionine and analyzing radiolabeled proteins by SDS-PAGE; (2) syncytium formation, characteristic of a productive $\mathrm{CCV}$ infection, was monitored microscopically by examination of infected cells $24 \mathrm{~h}$ after $\mathrm{CCV}$ infection; and (3) CCV replication was quantitated by plaque

\section{RESULTS}

\section{Viral interference: CRV protects $\mathrm{CCO}$ cells from rapid lysis by $\mathrm{CCV}$}

To determine the role that innate immunity plays in protecting teleosts from virus infection, we examined the possibility that interferon, or an interferon-like molecule, protected catfish cells against $\mathrm{CCV}$ infection. The ability of SCM from CRV-infected CCO cultures to block CCV replication was monitored by challenge assay as described in 'Methods'. We observed that $\mathrm{CCO}$ cells exposed to SCM from CRV-infected CCO cultures were protected against challenge with $\mathrm{CCV}$ (Fig. 1, rows 7 and 8, and row 14). In contrast, monolayers receiving SCM from mock-infected cells (data not shown) or medium alone (Fig. 1, row 12) were susceptible to infection. The protective effect of the SCM was stable at $\mathrm{pH} 2$ but was lost after heating $\left(30 \mathrm{~min}\right.$ at $\left.56^{\circ} \mathrm{C}\right)$ or following high speed centrifugation $(130000 \times g, 2 \mathrm{~h})$. These results, together with the observation that low dilutions of SCM from CRV-infected cultures induced CPE (Fig. 1, rows 3, 4, and 13), suggested that the anti-viral component was particulate and most likely infectious CRV rather than a soluble molecule such as interferon.

To confirm this result and to determine at what level CRV blocked CCV replication, CCO cells were exposed to either infectious CRV, UV-CRV, or a post-virion fraction obtained after centrifugation at $200000 \times g(\mathrm{~S} 200)$, and challenged with CCV 16 h later. As controls, CRV infection alone, CCV infection alone, or

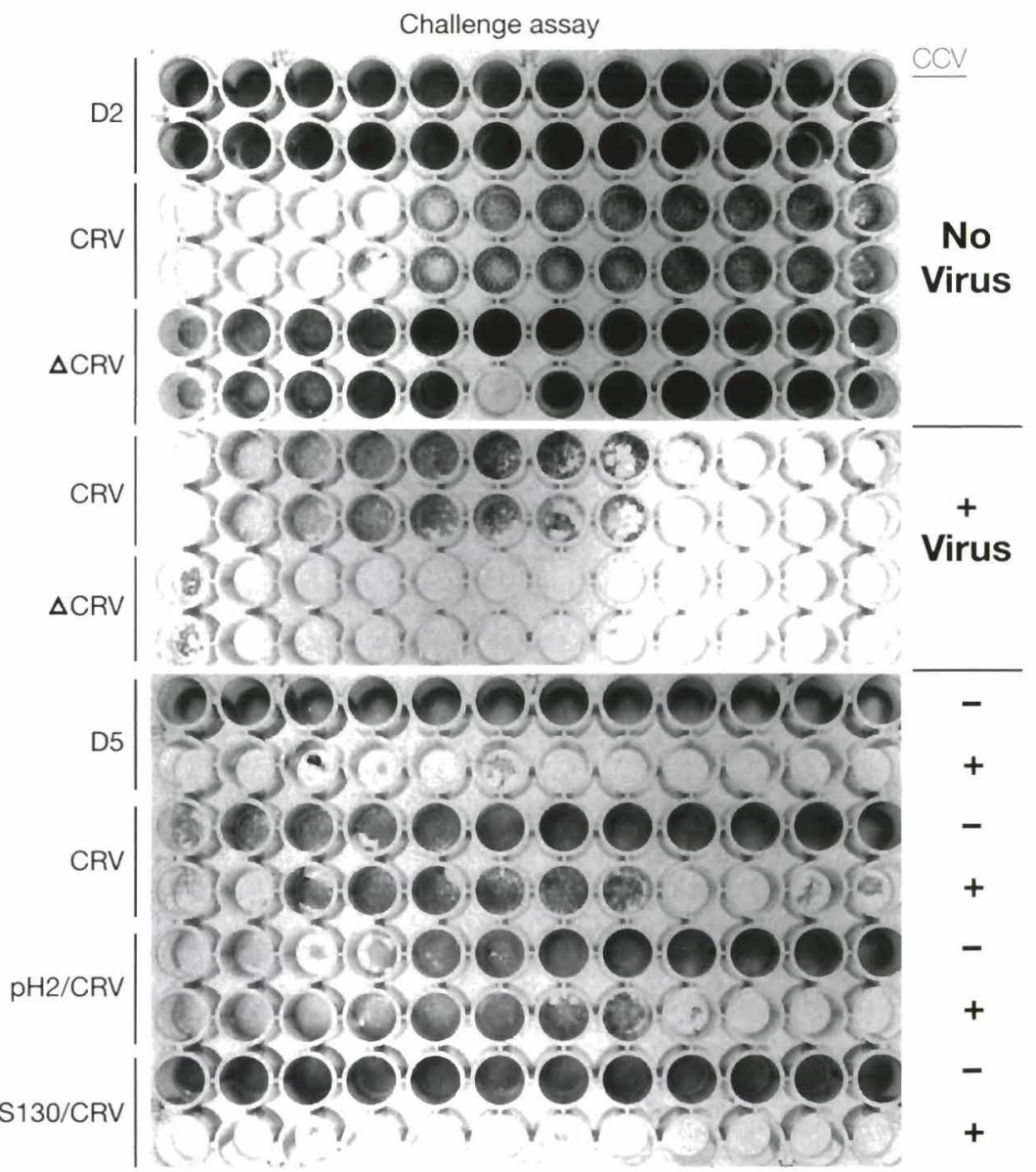

Fig. 1. Infectious CRV protects CCO cells from CCV challenge. Spent culture medium from CRV-infected CCO cells (CRV) was monitored in a challenge assay along with medium from CRV-infected cells that had been heatinactivated $(\triangle \mathrm{CRV})$, exposed to $\mathrm{pH} 2$ for $24 \mathrm{~h}$ ( $\mathrm{pH} 2 / \mathrm{CRV})$, or centrifuged at $130000 \times g$ for $2 \mathrm{~h}$ (S130/CRV). As a control, DMEM containing 2 or $5 \%$ FCS (D2 or D5) was also tested. The indicated media were serially diluted 2-fold (i.e. wells on the extreme left contain a 1:2 dilution, whereas those on the extreme right represent a dilution of 1:4096) and an equal volume (i.e. $100 \mu \mathrm{l}$ ) of $\mathrm{CCO}$ cell suspension added. After overnight incubation, $50 \mu \mathrm{l}$ of medium containing $\sim 1800 \mathrm{pfu} \mathrm{CCV}$ was added to the indicated wells. After $48 \mathrm{~h}$, the medium was removed and the cells stained with crystal violet. Protection is indicated by an intact, dye-stained monolayer (e.g. rows 1 and 2), whereas CPE and destruction of the monolayer is indicated by the absence of dye (e.g. rows 12 and 18). In the top 2 panels, duplicate samples were uninfected (rows 1 to 6 ) or challenged with CCV (rows 7 to 10 ). In the bottom panel, duplicate samples were mock-infected (-) or challenged with CCV (+) 
assay. We observed that prior infection with infectious CRV markedly reduced $\mathrm{CCV}$ protein synthesis in doubly infected cells (Fig. 2). Reduction of CCV protein synthesis was dependent upon the MOI of both CRV and CCV; higher inputs of CRV resulted in correspondingly higher levels of CCV inhibition, whereas elevated levels of CCV gave rise to more resistance to CRV-induced inhibition. We did not observe the synthesis of CRV-specific proteins in cells infected with UV-CRV or the S200 fraction, indicating that UVirradiation and high-speed centrifugation resulted, respectively, in the inactivation and removal of CRV virions. However, despite the absence of CRV protein synthesis, a slight inhibition in the level of early and late CCV proteins was noted. Furthermore, in cultures simultaneously infected with both CRV and CCV, CCV

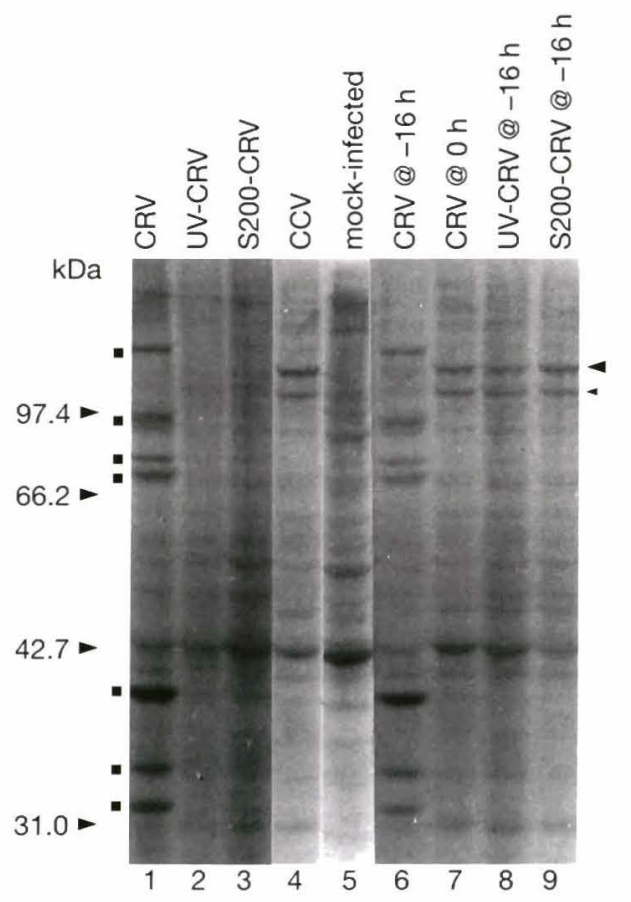

Fig. 2. Prior CRV infection blocks $\mathrm{CCV}$ protein synthesis. CCO cells were infected with 0.3 TCID $_{50}$ cell $^{-1}$ of CRV and subsequently super-infected with $0.8 \mathrm{pfu} \mathrm{cell}^{-1} \mathrm{CCV}$ immediately (lane 7 ) or $16 \mathrm{~h}$ later (lane 6). As controls, CCO cells were mock-infected (lane 5), or infected with CRV (lane 1) or $\mathrm{CCV}$ alone (lane 4). In addition, cells were infected with UVCRV (lane 2) or an S200 fraction prepared from infectious CRV (lane 3) at a nominal MOI of $0.3 \mathrm{pfu} \mathrm{cell}^{-1}$. Where indicated, cultures were super-infected with CCV 16 h after infection with UV-CRV or S200/CRV (lanes 8 and 9 respectively). Cells were radiolabeled with $\left[{ }^{35}\right.$ SImethionine 4 to $6 \mathrm{~h}$ after CCV infection (i.e. 20 to $22 \mathrm{~h}$ after infection with CRV) and radiolabeled proteins, separated by electrophoresis on $10 \%$ SDS-polyacrylamide gels, were visualized by autoradiography. Molecular weight markers are indicated in the left hand margin. To the right of the figure, a prominent CCV late protein is indicated by the large arrowhead, whereas a small arrowhead identifies a major early protein; to the left of the figure, several CRV proteins are indicated by filled squares replication was only slightly affected and CRV protein synthesis was not detected, suggesting that CRV replication, and not simply virus attachment or entry, was required for the inhibition of CCV gene expression.

To further characterize CRV-mediated interference, infected cultures were examined $24 \mathrm{~h}$ after CCV infection by light microscopy. As shown in Fig. 3, CRV infection blocked the appearance of characteristic CCV syncytium in a multiplicity dependent fashion. At both high $\left(\mathrm{MOI}=1.0 \mathrm{TCID}_{50}\right.$ cell $^{-1}$, panel AH) and low $\left(\mathrm{MOI}=0.1 \mathrm{TCID}_{50} \mathrm{cell}^{-1}\right.$, panel AL) input levels, CRV infection itself had minimal impact on the short-term viability of $\mathrm{CCO}$ monolayers. In contrast, $\mathrm{CCV}$ infection at high (MOI $=8$ pfu cell $^{-1}$, panel C1), intermediate $\left(\mathrm{MOI}=0.8 \mathrm{pfu} \mathrm{cell}^{-1}\right.$, panel C2), or low $(\mathrm{MOI}=0.08 \mathrm{pfu}$ $\mathrm{Cell}^{-1}$, panel C3) MOI led to extensive syncytium formation. In co-infected cultures, especially at lower inputs of CCV (i.e. panels BH3 and BL3), prior infection with CRV blocked the formation of CCV-induced syncytia most likely by blocking CCV-specific protein syn-

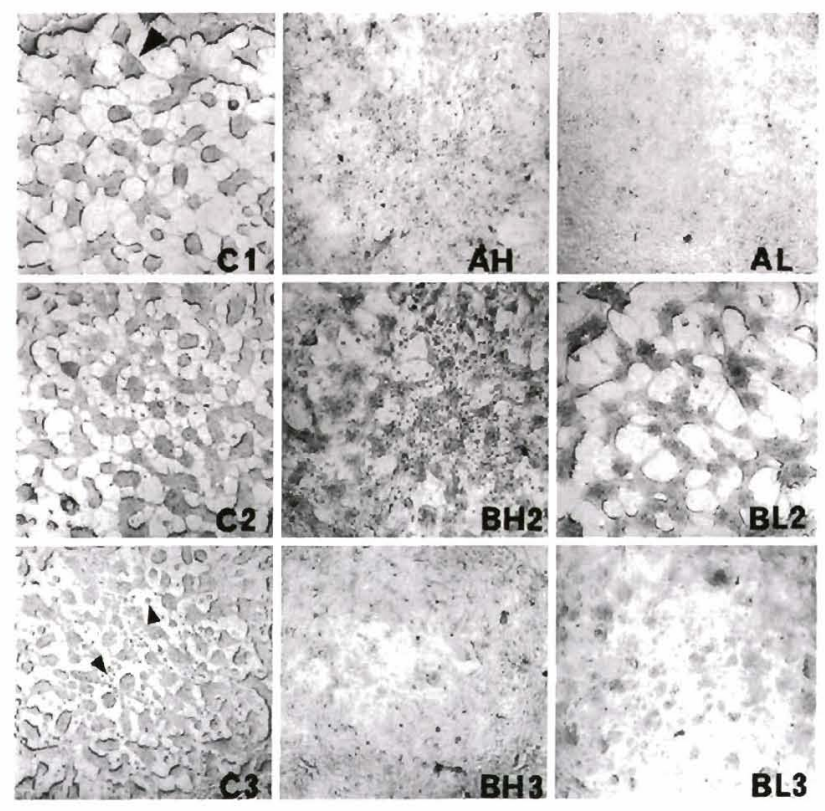

Fig. 3. CRV infection inhibits CCV-induced cell fusion. Confluent monolayers of $\mathrm{CCO}$ cells were infected with $\mathrm{CCV}$ alone (the 3 left-most panels) at 8 (panel C1), 0.8 (panel C2), or 0.08 pfu cell ${ }^{-1}$ (panel C3), with CRV alone $\left(\mathrm{MOI}=1 \mathrm{TCID}_{50}\right.$ cell $^{-1}$, panel $\mathrm{AH}_{\text {; }}$ and $\mathrm{MOI}=0.1 \mathrm{TCID}_{50}$ cell $^{-1}$, panel AL), or with a mix of CRV and CCV. In the later case, CRV infection was at either 1 (panels BH2 and BH3) or $0.1 \mathrm{TCID}_{50}$ cell $^{-1}$ (panels BL2 and BL3) and was initiated $16 \mathrm{~h}$ prior to infection with CCV at either 0.8 (panels BH2 and BL2) or 0.08 pfu cell $^{-1}$ (panels BH3 and BL3). Forty-eight hours after CCV infection, monolayers were examined for CCV-induced cell fusion and photographed to document the extent of cytopathic effect. The large arrowhead in panel C1 identifies a multi-nucleated cell characteristic of CCV-induced fusion. The smaller arrowheads in panel $\mathrm{C} 3$ identify individual $\mathrm{CCO}$ cells that are not part of a syncytium 
thesis. These results indicate that the reduction in CCV protein synthesis noted above in mixed infections was accompanied by a marked reduction in CCV-induced cell fusion.

To determine the effect of prior CRV infection on $\mathrm{CCV}$ virion formation, $\mathrm{CCV}$ titers in single and mixed infections were determined by plaque assay. As shown in Table 1, infection with CRV 16 h before superinfection with CCV resulted in markedly lower yields of the latter. Interestingly, whereas the $24 \mathrm{~h}$ yields of CCV were only about 2 -fold different following infection at either intermediate (i.e. $0.8 \mathrm{pfu} \mathrm{cell}^{-1}$ ) or low (i.e. $0.08 \mathrm{pfu} \mathrm{cell}^{-1}$ ) MOIs, prior infection with CRV had a 10 -fold greater inhibitory effect on the latter compared to the former. Furthermore, although simultaneous infection with CRV and CCV, or prior infection with UV-CRV or the S200 post-virion fraction at $16 \mathrm{~h}$ before CCV infection resulted in only a slight decrease in CCV protein synthesis (Fig. 2), a 70 to $90 \%$ decrease in virus yields was detected by plaque assay (Table 1). Taken together these results indicate that prior infection with CRV markedly reduced the replication of CCV in vitro.

\section{Induction of anti-viral activity by UV-CRV}

Since reoviruses are good inducers of interferon, we attempted to determine whether the protection mediated by treatment with UV-CRV might be attributable

Table 1. Yield reduction assay: effect of CRV infection on $\mathrm{CCV}$ yields. At the indicated times prior to infection with $\mathrm{CCV}$, cells were exposed to CRV $\left(\mathrm{MOI} \approx 0.9 \mathrm{TCID}_{50} \mathrm{cell}^{-1}\right)$, UV-CRV, or the high speed supernatant fraction (S200) prepared from culture medium harvested from CRV-infected cells. Twenty-four hours after CCV infection, cultures were frozen and $\mathrm{CCV}$ yields determined by plaque assay on $\mathrm{CCO}$ cells. In a typical experiment, CCV yields were $4.7 \times 10^{7} \mathrm{pfu}$ $\mathrm{ml}^{-1}$ following infection at an MOI of $0.8 \mathrm{pfu}^{-1} \mathrm{cell}^{-1}$, and $7.6 \times$ $10^{7} \mathrm{pfu} \mathrm{ml} \mathrm{m}^{-1}$ following infection at an MOI of $0.08 \mathrm{pfu} \mathrm{cell}^{-1}$. $\%$ Control $=(\mathrm{CCV}$ yield following pretreatment $\div \mathrm{CCV}$ yield in untreated cells) $\times 100$

\begin{tabular}{|c|c|c|c|c|}
\hline Expt & Treatment 1 & Time added & Treatment 2 & $\%$ Control \\
\hline \multirow[t]{5}{*}{$1^{\mathrm{a}}$} & CRV & $-16 \mathrm{~h}$ & $\mathrm{CCV}$ & $3.1 \pm 2.5$ \\
\hline & CRV & $0 \mathrm{~h}$ & $\mathrm{CCV}$ & $70 \pm 7.1$ \\
\hline & UV-CRV & $-16 \mathrm{~h}$ & $\mathrm{CCV}$ & $70 \pm 18$ \\
\hline & S200 & $-16 \mathrm{~h}$ & $\mathrm{CCV}$ & $115 \pm 47$ \\
\hline & None & - & $\mathrm{CCV}$ & 100 \\
\hline \multirow[t]{5}{*}{$2^{b}$} & CRV & $-16 \mathrm{~h}$ & $\mathrm{CCV}$ & $0.3 \pm 0.5$ \\
\hline & CRV & $0 \mathrm{~h}$ & $\mathrm{CCV}$ & $12.3 \pm 4.1$ \\
\hline & UV-CRV & $-16 \mathrm{~h}$ & $\mathrm{CCV}$ & $30 \pm 14$ \\
\hline & S200 & $-16 \mathrm{~h}$ & $\mathrm{CCV}$ & $34 \pm 22$ \\
\hline & None & - & $\mathrm{CCV}$ & 100 \\
\hline \multicolumn{5}{|c|}{${ }^{\mathrm{a}}$ In Expt $1 \mathrm{CCV}$ MOI was $0.8 \mathrm{pfu} \mathrm{cell}^{-1}$} \\
\hline
\end{tabular}

to the in situ induction of an anti-viral factor (AVF) rather than to viral interference. $\mathrm{CCO}$ cells were infected with UV-CRV, and at $24 \mathrm{~h}$ intervals culture medium was harvested and tested for its ability to block CCV replication using a standard challenge assay. We observed (Fig. 4) that CCO cells synthesized (or secreted) an AVF following infection with UV-CRV. The titer of the AVF was higher in cultures infected with 1.0 versus 0.1 TCID $_{50}$ cell $^{-1}$ UV-CRV. For example on Day 2, the anti-viral titer in cells infected at the lower MOI was $160 \mathrm{IU} \mathrm{ml}^{-1}$, whereas the titer in cells infected at the higher MOI was $2560 \mathrm{IU} \mathrm{m}{ }^{-1}$. Maximal levels of AVF were seen within 24 to $48 \mathrm{~h}$ after infection and did not increase appreciably over the next $2 \mathrm{~d}$. No anti-viral activity was detected in SCM harvested before CRV infection or from medium harvested from mock-infected cultures during the $4 \mathrm{~d}$ course of this experiment.

In a subsequent series of experiments the resistance of cells which synthesized (or secreted) anti-viral activity was monitored. CCO cells were infected with UVCRV and culture medium harvested daily as described above. On the day media were harvested, the cultures were challenged with $\mathrm{CCV}$ and monitored 48 h later for the development of $\mathrm{CPE}$ and the production of infectious CCV. We observed that mock-treated $\mathrm{CCO}$ cells were readily susceptible to $\mathrm{CCV}$ infection and showed marked CPE within $48 \mathrm{~h}$ after low MOI infection with CCV, whereas UV-CRV-infected cultures showed little CPE (data not shown). Furthermore, the reduction of $\mathrm{CPE}$ correlated with a marked reduction in the ability of UV-CRV-infected CCO cells to support $\mathrm{CCV}$ replication. CCO cells treated 24 to $48 \mathrm{~h}$ earlier with UV-inactivated CRV then challenged with infectious CCV showed $48 \mathrm{~h} \mathrm{CCV}$ yields $\sim 5 \%$ of those seen in mock-treated cells (average of 3 experiments). Surprisingly, protection was not long-lasting, and by $72 \mathrm{~h}$ after CCV infection UV-CRV-treated cultures showed marked CPE (data not shown).

\section{Constitutive production of anti-viral activity by long-term, catfish lymphoid cell lines}

In addition to the anti-viral activity generated in CCO cells following infection with UV-CRV, anti-viral activity was also constitutively present in SCM harvested from several long-term, catfish $\mathrm{T}$ cell-like and macrophage lines. Anti-viral titers as high as $6400 \mathrm{IU}$ $\mathrm{ml}^{-1}$ were detected in SCM from CF-59 (a T cell-like line). Moreover, the activity present in supernatants from 42TA cells (a macrophage line) was reduced 10-fold (from 1280 to $120 \mathrm{IU} \mathrm{ml}^{-1}$ ) by boiling for $10 \mathrm{~min}$, suggesting that the inhibitor was a heat-labile protein. Interestingly, anti-viral activity was not detected in 


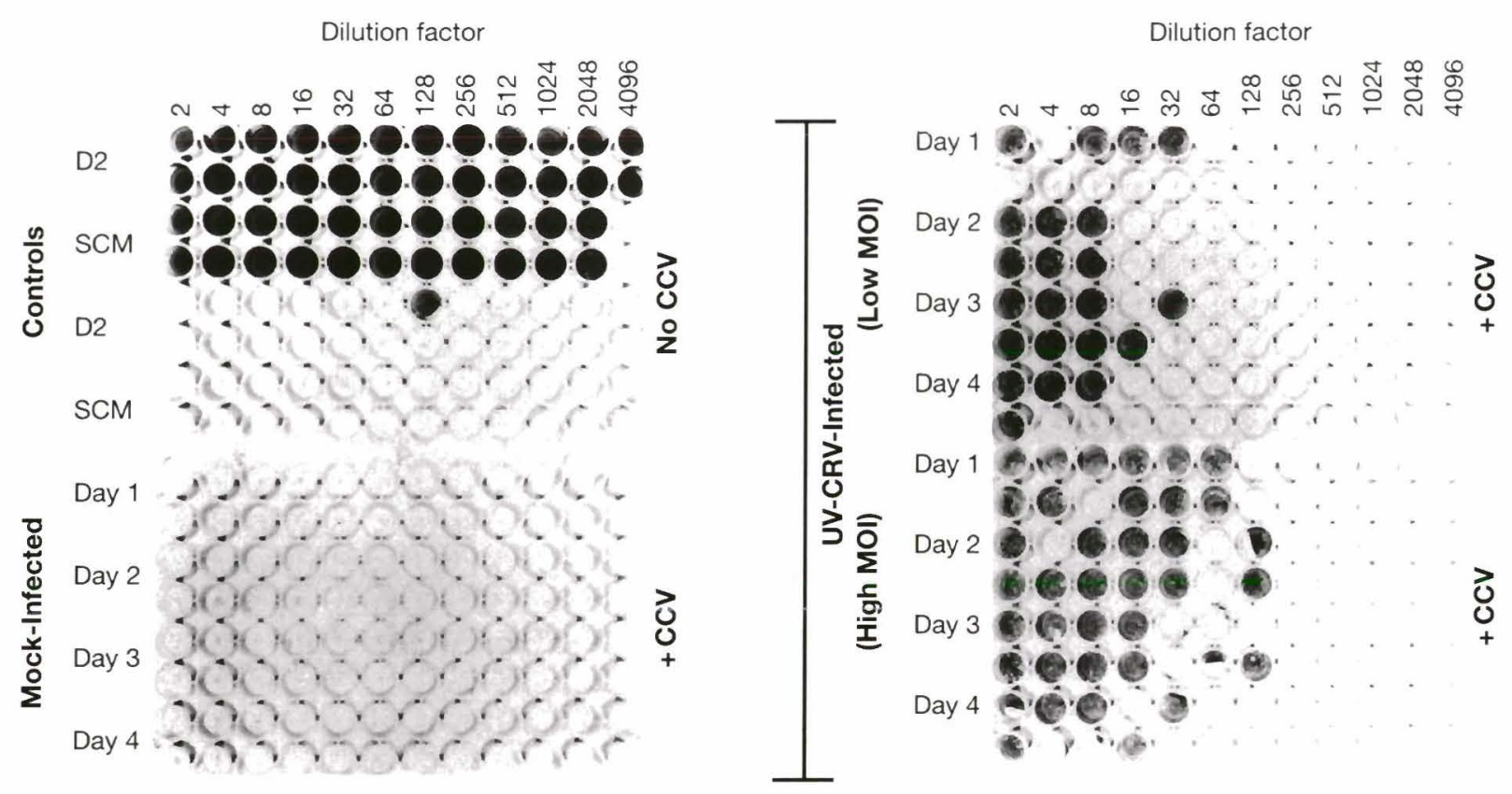

Fig. 4. Spent culture medium from CCO cells infected with UV-CRV protects CCO cells from infection with CCV. Four days after plating, CCO cells were mock-infected or infected with UV-CRV at a nominal MOI of $1 \mathrm{TCID}_{50}$ cell $^{-1}$ ('high MOI') or $0.1 \mathrm{TCID}_{50}$ cell $^{-1}$ ('low MOI'). At daily intervals the spent culture medium was removed, clarified by low speed centrifugation, and frozen until assay. Medium harvested at various days post infection, as well as spent culture medium (SCM) from CCO cells harvested prior to assay and DMEM/2\% FCS (D2) were tested for anti-viral activity by challenge assay. The dilution factor (before addition of an equal volume of $\mathrm{CCO}$ cell suspension) is indicated above each column. The first 4 rows in the 'control' plate were mockinfected ('No CCV'), while all other wells on this and the remaining 3 plates were challenged with $\mathrm{CCV}$ ('+CCV')

SCM harvested from cloned B cell (e.g. 1G8) or fibroblast lines (F59 and CCO) not infected with CRV. In some experiments, growth medium from catfish peripheral blood lymphocytes (PBLs) proliferating in mixed lymphocyte culture (MLC) blocked CCV infection. Taken together, these results suggest that longterm catfish lymphoid cells may be an excellent source of fish cytokines.

\section{DISCUSSION}

The above work suggests that CRV interferes with CCV replication by 2 possible mechanisms: viral interference and induction of an AVF. Infection with CRV $16 \mathrm{~h}$ prior to infection with CCV blocked CCV as well as cellular macromolecular synthesis. Although the precise mechanism of inhibition of CCV by CRV has not yet been determined, it is likely that aquareoviruses, like their mammalian counterparts, block heterologous gene expression and regulate expression of their own products in a complex fashion (Nibert et al. 1996). In mammalian systems, reovirus infection leads to activation of DAI, a dsRNA-activated kinase, which specifically phosphorylates and inactivates the $\alpha$ subunit of eukaryotic initiation factor 2 (eIF-2) (Nilsen et al.
1982, Hovanessian 1991). Although phosphorylation of eIF- $2 \alpha$ leads to a global block in cellular protein synthesis, reovirus translation is maintained due to high, localized concentrations of the reovirus protein $\delta 3$, which binds dsRNA and blocks activation of DAI (Schmechel et al. 1997). In cells infected with CRV alone translational shutoff results in the gradual replacement of cellular gene expression by reovirus, whereas in cells co-infected with CRV and CCV, CRV infection appears to suppress both host and heterologous virus gene expression. Inspection of Fig. 2 supports this view and shows that in CRV-infected cells reovirus proteins are clearly seen against a background of diminished cellular protein synthesis. Furthermore, the marked inhibition of cellular protein synthesis following CRV infection may also explain why only low levels of the AVF are synthesized in productively-infected cells, i.e. inhibition of cellular protein synthesis prevents the accumulation of high levels of the AVF.

Viral interference has been reported following infection of fish or fish cell lines with homologous or heterologous viruses (Nicholson \& Dunn 1974, de Kinkelin et al. 1992). Hedrick et al. (1994) showed that preexposure of rainbow trout to avirulent cutthroat trout virus (CTV) reduced mortality associated with subsequent infection by infectious hematopoietic necrosis 
virus (IHNV). The mechanism(s) of resistance induced by CTV was unknown, but CTV was found to be a potent inducer of interferon-like activity. In a second study, LaPatra et al. (1995) showed that prior infection of rainbow trout with avirulent chum salmon reovirus resulted in increased survival when the fish were challenged with IHNV over an 8 wk period. As with the previous study, the mechanism of protection was unknown although it was suggested that protection may involve interferon induction and/or stimulation of macrophage or natural killer cell functions.

Following exposure to UV-CRV, anti-viral activity was induced and reached maximal levels within 24 to $48 \mathrm{~h}$ (Fig. 4). The kinetics of AVF induction in CCO cells cultured at $27^{\circ} \mathrm{C}$ are nearly as rapid as interferon induction in mammalian cells incubated at $37^{\circ} \mathrm{C}$, and are consistent with the proposed role of interferon as a first line of defense following virus infection. Protection afforded by catfish AVF was incomplete and could be overcome by increasing the input of challenge virus. Furthermore, although cultures producing AVF were protected from $\mathrm{CCV}$ challenge for $\sim 48 \mathrm{~h}$, during the next $24 \mathrm{~h}$ 'residual' virus replicated and caused extensive CPE. The basis for this phenomoneon is not known but may reflect waning of the anti-viral state. Consistent with this observation are findings in other systems where the protection mediated by interferon could only be demonstrated when the input level of challenge virus was low (Pusateri et al. 1980). Alternatively, it is possible that the system chosen to monitor anti-viral activity (i.e. CCV infection of CCO cells) is not optimal for assessing activity. $\mathrm{CCV}$, as is the case with other large DNA viruses, may encode proteins which antagonize interferon action, and CCO cells may not be as sensitive to the induction of anti-viral proteins as other cell types. Furthermore, marked variation is seen among piscine herpesviruses in their sensitivity to interferon (Frerichs 1989).

In addition to induction with UV-CRV, anti-viral activity was constitutively present in several longterm, catfish lymphoid cell lines. Levels of anti-viral activity, similar to those seen following UV-CRV infection, were detected in supernatants harvested from $\mathrm{T}$ cell-like (CF-59) and macrophage ( 42TA) cell lines. In contrast, B cell clones (1G8) and fibroblast cell lines (F59, CCO) did not constitutively produce AVF. Previous work showed that newly established $\mathrm{T}$ cell and macrophage lines were non-permissive for CCV replication (Chinchar et al. 1993). In view of the above findings, this defect may be due to the production of an AVF by these cultures. Interestingly, as T cell/macrophage lines were maintained in culture, they gradually became more permissive to $\mathrm{CCV}$ infection, perhaps because they lost their ability to synthesize 'nonessential' proteins (e.g. cytokines). Consistent with this suggestion, long-term catfish lymphoid cell lines, which initially secreted compounds functionally homologous to IL-2 and IL-4, lost their ability to synthesize and/or secrete these 'luxury' proteins with continued in vitro passage (C. Luft \& N. W. Miller pers. comm.).

Although an AVF has been detected in catfish cells by its biological activity, its identity has not yet been determined. Furthermore, it is not clear whether the anti-viral activity seen in CCO cultures after infection with UV-CRV and the activity detected constitutively in long-term lymphoid cell lines are identical. It is possible that the activity induced by UV-CRV in fibroblasts is type I interferon (interferon $\alpha / \beta$ ), whereas the activity seen in $\mathrm{T}$ cells and macrophages is related to type II interferon (interferon $\gamma$ ). Cytokine activity has been detected in catfish lymphoid cell cultures following mitogen stimulation (Caspi \& Avtalion 1984, Grondel \& Harmsen 1984, Clem et al. 1985, Miller et al. 1985, Lin et al. 1992, Clem et al. 1996). Furthermore, rapidly proliferating MLC cultures contain increased numbers of activated natural killer and/or T cells (Stuge et al. 1997) and likely synthesize interferon $\gamma$ and a variety of other cytokines. Consistent with these results, Graham \& Secombes (1990) found that an interferon $\gamma$-like activity was secreted by trout leukocytes following mitogen stimulation. However, attempts in our laboratory to detect mRNA encoding type I interferon or tumor necrosis factor (TNF) $\alpha$ in long-term catfish lymphoid cell lines by Northern blot analysis using mammalian probes for TNF $\alpha$, interferon $\alpha$, and interferon $\beta$ or by reverse transcription polymerase chain reaction (RT-PCR) were not successful. These results suggest either the absence of interferon $\alpha / \beta$ and TNF $\alpha$ transcripts in these cells or that the piscine genes encoding these proteins may be only distantly related to their mammalian homologs. The latter view is strengthened by recent studies showing that chicken interferon genes share little sequence identity with their mammalian counterparts (Sekellick et al. 1994, Lowenthal et al. 1995). Thus, while the AVF may be piscine interferon, definitive proof awaits additional physio-chemical and genetic confirmation.

In summary, the work described herein provides evidence of virus-mediated interference in catfish, and is the first report of an interferon-like, anti-viral activity in this species. The ability of CCO cells to synthesize detectable levels of an interferon-like factor following infection with UV-CRV, coupled with the ability of several lymphoid cell lines to synthesize AVF constitutively, suggests that catfish may be an excellent system in which to study piscine interferon-like activity and explore the evolutionary origins of this important component of innate immunity. This system may provide the key which will allow researchers to progress beyond the mere description of interferon-like activity in fish and definitively identify these important cytokines. 
Acknowledgements. This work was supported by USDA awards 94-37204-0853 and 94-37204-2225.

\section{LITERATURE CITED}

Amend DF, McDowell T, Hedrick RP (1984) Characteristics of a previously unidentified virus from channel catfish (Ictalurus punctatus). Can J Fish Aquat Sci 41:807-811

Aubertin AM, Guir J, Kirn A (1970) The inhibition of vaccinia virus DNA synthesis in KB cells infected with frog virus 3. J Gen Virol 8:105-111

Beasley AR, Sigel MM, Clem LW (1966) Latent infection in marine fish cell tissue cultures. Proc Soc Exp Biol Med 121:1169-1174

Bowser PR, Plumb JA (1980a) Growth rates of a new cell line from channel catfish ovary and channel catfish virus replication at different temperatures. Can J Fish Aquat Sci 37:871-873

Bowser PR, Plumb JA (1980b) Channel catfish virus: comparative replication and sensitivity of cell lines from channel catfish ovary and the brown bullhead. J Wildl Dis 16: 451-454

Caspi RR, Avtalion RR (1984) Evidence for the existence of an IL-2-like lymphocyte growth promoting factor in bony fish. Dev Comp Immunol 8:51-60

Chinchar VG, Caughman GB (1986) Heat inactivated frog virus 3 selectively inhibits EHV-1 translation in a temporal class dependent manner. Virology 152:466-471

Chinchar VG, Rycyzyn M, Clem LW, Miller NW (1993) Productive infection of continuous lines of channel catfish leukocytes by channel catfish virus. Virology 193:989-992

Clem LW, Bly JE, Wilson M, Chinchar VG, Stuge T, Barker K, Luft C, Rycyzyn M, Hogan RJ, van Lopik T, Miller NW (1996) Fish immunology: the utility of immortalized lymphoid cells - a mini review. Vet Immunol Immunopathol 54:137-144

Clem LW, Sizemore RC, Ellsaesser CF, Miller NW (1985) Monocytes as accessory cells in fish immune responses. Dev Comp Immunol 9:803-809

de Kinkelin P, Dorson M, Renault T (1992) Interferon and viral interference in viruses of salmonid fish. In: Kimura $\mathrm{T}$ (ed) Proceedings of the OJI International Symposium on Salmonid Fish. Hokkaido University Press, Sapporo, p 241-249

De Sena J, Rio GJ (1975) Partial purification and characterization of RTG-2 fish cell interferon. Inf Immun 11:815-822

Eaton WD (1990) Anti-viral activity in four species of salmonids following exposure to poly inosinic:cytidylic acid. Dis Aquat Org 9:193-198

Frerichs GN (1989) Rhabdoviruses of fishes. In: Ahne W, Krustak E (eds) Viruses of lower vertebrates. SpringerVerlag, New York, p 317-332

Graham S, Secombes CJ (1990) Do fish lymphocytes secrete interferon- $\gamma$ ? J Fish Biol 36:563-573

Grondel JL, Harmsen EGM (1984) Phylogeny of interleukines: growth factors produced by leukocytes of cyprinid fish, Cyprinus carpio L. Immunol 52:477-482

Hedrick RP, LaPatra SE, Yun S, Lauda, KA, Jones GR, Congleton JL, de Kinkelin P (1994) Induction of protection from infectious hematopoietic necrosis virus in rainbow trout (Oncorhynchus mykiss) by pre-exposure to the avirulent cutthroat virus (CTV). Dis Aquat Org 20: $111-118$

Hovanessian AG (1991) Interferon-induced and dsRNAactivated enzymes: a specific protein kinase and $2{ }^{\prime} 5^{\prime}$ oligoadenylate synthetase. J Interferon Res 11:199-205

Laemmli UK (1970) Cleavage of structural proteins during assembly of the head of bacteriophage T4. Nature 227: $680-685$

LaPatra SE, Lauda KA, Jones GR (1995) Aquareovirus interference mediated resistence to infectious hematopoietic necrosis virus. Vet Res 26:455-459

Lin GL, Ellsaesser CF, Clem LW, Miller NW (1992) Phorbol ester/calcium ionophore activate fish leukocytes and induce long-term cultures. Dev Comp Immunol 16:153-163

Lowenthal JW, Digby MR, York JJ (1995) Production of interferon $\gamma$ by chicken $T$ cells. J Interferon Cytokine Res 15: 933-938

Marcus PI (1994) Interferons. In: Webster RG, Granoff A (eds) Encyclopedia of virology. Academic Press, London, p 733-739

Miller NW, Chinchar VG, Clem LW (1994a) Development of leukocyte cell lines from the channel catfish (Ictalurus punctatus). J Tissue Cult Methods 16:117-123

Miller NW, Rycyzyn MA, Wilson MR, Warr GW, Naftel JP, Clem LW (1994b) Development and characterization of channel catfish long-term B cell lines. J Immunol 152: $2180-2189$

Miller NW, Sizemore RC, Clem LW (1985) Phylogeny of lymphocyte heterogeneity: the cellular requirements for in vitro antibody responses. J Immunol 134:2884-2888

Nibert ML, Schiff LA, Fields BN (1996) Reoviruses and their replication. In: Fields BN, Knipe DM, Howley PM (eds) Fundamental virology, 3rd edn. Lippincott-Raven, Philadelphia, p 691-730

Nicholson BL, Dunn J (1974) Homologous viral interference in trout and Atlantic salmon cell cultures infected with infectious pancreatic necrosis virus. J Virol 14:180-182

Nilsen TW, Maroney PA, Baglioni C (1982) Inhibition of protein synthesis in reovirus-infected HeLa cells with elevated levels of interferon-induced protein kinase activity. J Biol Chem 257:14593-14598

Oie HK, Loh PC (1971) Reovirus type 2: induction of viral resistance and interferon production in fathead minnow cells. Proc Soc Exp Biol Med 136:369-373

Pusateri AM, Ewalt LC, Lodmell DL (1980) Nonspecific inhibition of encephalomyocarditis virus replication by a type II interferon released from unstimulated cells of $M$. tuberculosis-sensitized mice. J Immunol 124:1277-1283

Ramig RF (1990) Principles of animal virus genetics. In: Fields BN, Knipe DM (eds) Virology. Raven Press, New York, p 95-122

Reed LJ, Muench H (1938) A simple method of estimating fifty percent end points. Am J Hyg 27:493-497

Renault T, Torchy C, de Kinkelin P (1991) Spectrophotometric method for titration of trout interferon, and its application to rainbow trout fry experimentally infected with viral hemorrhagic septicemia virus. Dis Aquat Org 10:23-29

Rogel-Gaillard C, Chilmonczyk S, de Kinkelin P (1993) In vitro induction of interferon-like activity from rainbow trout leukocytes stimulated by Egtved virus. Fish Shellfish Immunol 3:383-394

Schmechel S, Chute M, Skinner P, Anderson R, Schiff L (1997) Preferential translation of reovirus mRNAs by a $\delta 3$ dependent mechanism. Virology 232:62-73

Sekellick MJ, Ferrandino AF, Hopkins DA, Marcus PI (1994) Chicken interferon gene: cloning, expression, and analysis. J Interferon Res 14:71-79

Snegaroff J (1993) Induction of interferon synthesis in rainbow trout leucocytes by various homeotherm viruses. Fish Shellfish Immunol 3:191-198

Steck F, Rubin H (1966) The mechanism of interference between an avian leukosis virus and Rous sarcoma virus. I. Establishment of interference. Virology 29:628-641 
Stuge TB, Yoshida SH, Chinchar VG, Miller NW, Clem LW (1997) Cytotoxic activity generated from channel catfish periperal blood leukocytes in mixed leukocyte cultures. Cell Immunol 177:154-161

Tannenbaum J, Goorha RG, Granoff A (1979) The inhibition of VSV protein synthesis by frog virus 3. Virology 96:227-231

Vilcek J, Sen GC (1996) Interferon and other cytokines. In: Fields BN, Knipe DM, Howley PM (eds) Fundamental virology, 3rd edn. Lippincott-Raven, Philadelphia, p 341-365 Weissmann C, Weber H (1996) The interferon genes. Prog Nucleic Acid Res 33:251-300

Editorial responsibility: Jo-Ann Leong,

Corvallis, Oregon, USA
Wilson MR, Bengten E, Miller NW, Clem LW, Du Pasquier L, Warr GW (1997) A novel chimeric Ig heavy chain from a teleost fish shares similarities to IgD. Proc Natl Acad Sci USA 94:4593-4597

Yano $T$ (1996) The non-specific immune system: humoral defense. In: Iwama G, Nakanishi T (eds) The fish immune system: organism, pathogen, and environment. Academic Press, San Diego, p 105-157

Younger JS, Whitaker-Dowling P (1994) Interference. In: Webster RG, Granoff A (eds) Encyclopedia of virology. Academic Press, San Diego, p 728-732

Submitted: December 19, 1997; Accepted: March 26, 1998 Proofs received from author(s): June 6, 1998 
